\title{
Rhipicephalus (Boophilus) microplus: expression and characterization of Bm86-CG in Pichia pastoris
}

Rhipicephalus (Boophilus) microplus: expressão e caracterização da Bm86-CG em Pichia pastoris

Rodrigo Casquero Cunha ${ }^{1}$; Renato Andreotti2*; Fábio Pereira Leivas Leite ${ }^{3}$

${ }^{1}$ Universidade Federal de Mato Grosso do Sul - UFMS

${ }^{2}$ Laboratory of Molecular Biology, Department of Animal Health, EMBRAPA Beef Cattle

${ }^{3}$ Department of Microbiology and Parasitology, Institute of Biology, Universidade Federal de Pelotas - UFPel

Received July 12, 2010

Accepted December 14, 2010

\begin{abstract}
The cattle tick Rhipicephalus (Boophilus) microplus is responsible for great economic losses. It is mainly controlled chemically, with limitations regarding development of resistance to the chemicals. Vaccines may help control this parasite, thereby reducing tick pesticide use. In this light, we performed subcloning of the gene of the protein Bm86-GC, the homologue protein that currently forms the basis of vaccines (Gavac ${ }^{\mathrm{TM}}$ and TickGard ${ }^{\text {PLUS }}$ ) that have been developed against cattle ticks. The subcloning was done in the pPIC9 expression vector, for transformation in the yeast Pichia pastoris. This protein was characterized by expression of the recombinant $\mathrm{Mut}^{+}$strain, which expressed greater quantities of protein. The expressed protein ( $\mathrm{rBm} 86-\mathrm{CG})$ was recognized in the Western-blot assay using anti-Gavac, antiTickGard, anti-larval extract and anti-rBm86-CG polyclonal sera. The serum produced in cattle vaccinated with the antigen CG rBm86 presented high antibody titers and recognized the native protein. The rBm86-GC has potential relevance as an immunogen for vaccine formulation against cattle ticks.
\end{abstract}

Keywords: Ixodes, ticks, bovines, rBm86-CG, immunization.

\section{Resumo}

O carrapato-do-boi Rhipicephalus (Boophilus) microplus é responsável por grandes perdas econômicas. Seu controle é principalmente químico e apresenta limitações quanto ao desenvolvimento de resistência aos princípios ativos. As vacinas podem auxiliar no controle deste parasita diminuindo as aplicaçôes de carrapaticidas. Considerando isso, foi realizada a subclonagem do gene da proteína Bm86-CG, proteína homologa a que atualmente é a base das vacinas desenvolvidas (Gavac ${ }^{\mathrm{TM}}$ e TickGard ${ }^{\mathrm{PLUS}}$ ) contra o carrapato-do-boi, no vetor de expressáo pPIC9, para ser transformado em levedura, Pichia pastoris. Esta proteína foi caracterizada pela expressão da cepa recombinante Mut $^{+}$que expressou maior quantidade de proteína. A proteína expressa, rBm86-CG, foi reconhecida no ensaio de Western-blot pelos soros policlonais anti-Gavac, anti-TickGard, anti-Extrato de larva e anti-rBm86-CG. O soro produzido em bovinos vacinados com o antígeno rBm86-CG apresentou altos títulos de anticorpo e reconheceu a proteína nativa. A rBm86-CG possui potencial relevância como imunógeno para formulação vacinal contra o carrapato de bovinos.

Palavras-chave: Ixodes, carrapatos, bovinos, rBm86-CG, imunização.

\section{Introduction}

Considerable economic losses are currently caused by Rhipicephalus (Boophilus) microplus, a cattle ectoparasite occurring in tropical and subtropical areas (WILLADSEN; JONGEJAN, 1999). Chemical control, albeit predominant, has been hampered by poor utilization of active agents, thus leading to development of resistance and requiring the use of higher concentrations of active compounds and more frequent application, year by year

\footnotetext{
${ }^{*}$ Corresponding author: Renato Andreotti

Embrapa Beef Cattle, BR 262, Km 04, CP 154,

CEP 79002-970, Campo Grande - MS, Brazil;

e-mail: andreott@cnpgc.embrapa.br
}

(FURLONG, 2004). Vaccines are an alternative for tick infestation control. In association with tick pesticides, they can reduce the use of these agents, thereby lowering the costs of animal production, levels of environmental contamination and presence of residues in animal-derived products (GARCÍA-GARCÍA et al., 2000).

The protein $\mathrm{Bm} 86$ is one of the antigens most used in vaccines against $R$. (B.) microplus, and it yields satisfactory results in tick control (DE LA FUENTE et al., 1998; 1999; PATARROYO et al., 2002; WILLADSEN; KEMP, 1988; WILLADSEN; MCKENNA, 1991; WILLADSEN et al., 1989). It is a glycoprotein predominantly located in the membrane of tick gut cells (GOUGH; KEMP, 1993). 
When this protein is used as a vaccine antigen, the antibodies bind to the surface of epithelial cells in the tick intestine. This causes cell lysis and reduces reproductive efficiency among engorged females (WILLADSEN, 1997), since these cells are probably implicated in the mechanism of endocytosis (RIDING et al., 1994).

In the state of Mato Grosso do Sul, Brazil, a previous study on two vaccine formulations based on $\mathrm{Bm} 86$, namely, TickGard ${ }^{\text {PLUS }}$ (Intervet Australia Pty. Ltd., 91-105 Harpin Street, Bendigo East, Victoria, Australia) and Gavac ${ }^{\mathrm{TM}}$ (Heber Biotec S.A., Havana, Cuba), yielded effectiveness rates of 46.4 and $49.2 \%$, respectively, regarding protection against this cattle tick (ANDREOTTI, 2006). However, these levels were lower than those achieved in other regions around the world (DE LA FUENTE et al., 1999; PATARROYO et al., 2002; RAND et al., 1989; RICHARDSON et al., 1993).

In a recent investigation, Andreotti et al. (2008) compared the predicted amino acid sequences of Bm86-CG (Gen Bank accession no. ACA57829) with those of Bm86 (Gen Bank accession no. M29321.1) and Bm95 (Gen Bank accession no. AF150891) and found identity levels of 96.5 and $96.3 \%$, respectively. The study suggested that two differences in the Bm86-CG sequence in hydrophobic regions may have great potential for influencing the dynamics of antibody recognition. This might account for the low effectiveness of Gavac ${ }^{\mathrm{TM}}$ for protecting cattle raised in the Campo Grande region, against locally isolated infestation by R. (B.) microplus (ANDREOTTI, 2006).

A number of vaccines based on recombinant $\mathrm{Bm} 86$ have been formulated (CANALES et al., 2009; DE LA FUENTE et al., 1999; PATARROYO et al., 2002; RAND et al., 1989; RODRIGUEZ et al., 1995). However, these have varying effectiveness levels against cattle tick strains from different geographic areas. This feature is possibly related to natural allele variations in the $\mathrm{Bm} 86$ gene (DE LA FUENTE; KOCAN, 2003). Differences in amino acid sequence in $\mathrm{Bm} 86$ variations of more than $3.4 \%$ would be sufficient to make vaccination ineffective against different strains of the tick (GARCÍA-GARCÍA et al., 1999).

The purpose of the present study was to produce a regional antigen containing the partial sequence of $\mathrm{Bm} 86-\mathrm{CG}_{21-603}$, using a eukaryotic expression system based on Pichia pastoris. This system was selected because Bm86-CG is a glycoprotein and because $P$. pastoris is capable of effecting glycosylation and correctly folding the recombinant protein. These factors may be decisive in determining the composition of the three-dimensional structure of this protein, and therefore the effectiveness of antibody production.

\section{Material and Methods}

\section{Bm86-CG sequence}

Bm86-CG (GenBank accession no. EU352677.1) was used as a template. Briefly, this sequence was amplified from total cDNA of larval $R$. (B.) microplus and cloned into plasmid pMOS blue (GE Healthcare, United Kingdom) (ANDREOTTI et al., 2008). The 1825-bp DNA fragment corresponding to Bm86-CG was amplified from plasmid pMOS blue by means of PCR using the primers BmCG-EcoRI-F1 (CGGAATTCTCATCCATTTGCTC) and BmCG-NotI-R2 (GCGGCCGCAGCACTTGACTT) (both synthesized by Invitrogen, Australia) in a Mastercycler personal thermal cycler (Eppendorf, Germany).

\section{Construction of plasmid pPIC9BmCG}

The vector pPIC9 (Invitrogen, Australia) was selected for subcloning the gene to be expressed by $P$. pastoris. The vector was transformed into chemically competent top 10F' E. coli cells using the heat-shock method (INVITROGEN, 2009) to promote propagation. Because the plasmid included a gene that confers ampicillin resistance to successfully transformed Escherichia coli cells, these were inoculated into $10 \mathrm{~mL}$ of LB medium containing $100 \mu \mathrm{g} . \mathrm{mL}^{-1}$ of ampicillin and incubated overnight in an orbital shaker at $37^{\circ} \mathrm{C}$. The pPIC9 vector was extracted from the cells using a NucleoSpin plasmid kit (Macherey-Nagel, Germany) and then eluted in water.

The purified PCR product and the pPIC9 vector were initially incubated with the EcoRI enzyme (Promega, USA) and subsequently with the NotI enzyme (Promega, USA), in accordance with to the manufacturer's instructions, separately. The resulting material was purified using the NucleoSpin Extract II kit (Macherey-Nagel, Germany) and finally eluted in Milli-Q water. Amounts of digested PCR product (34 ng) and digested pPIC9 (50 ng) were incubated in a system containing the T4 DNA-ligase enzyme (Promega, USA), in accordance with the manufacturer's instructions, and were incubated overnight at $4^{\circ} \mathrm{C}$. The ligation was subjected to agarose gel electrophoresis $(0.8 \%)$ and was quantified by means of UV spectrophotometry. A $10 \mu \mathrm{L}$ aliquot of the ligation system was transformed into chemically competent top 10F' E. coli using the heat-shock method (WILEY, 2003). The transformed cells were seeded in petri dishes containing LB agar amended with $100 \mu \mathrm{g} . \mathrm{mL}^{-1}$ of ampicillin and incubated for two days at $37^{\circ} \mathrm{C}$. Ten colonies were selected for subculturing in $50 \mathrm{~mL}$ Falcon tubes containing $10 \mathrm{~mL}$ of LB medium with $100 \mu \mathrm{g} \cdot \mathrm{mL}^{-1}$ of ampicillin, and these were incubated overnight in an orbital shaker at $120 \mathrm{rpm}$ at $37^{\circ} \mathrm{C}$. From each sample, $500 \mu \mathrm{L}$ aliquots were collected to be centrifuged and resuspended in $500 \mu \mathrm{L}$ of LB medium with $15 \%$ glycerol for storage at $-80{ }^{\circ} \mathrm{C}$. From the remaining $9.5 \mathrm{~mL}$, the recombinant plasmid was extracted using a NucleoSpin plasmid kit (Macherey-Nagel, Germany). Insertion was confirmed by subjecting each plasmid to PCR with 5'AOX1 and 3'AOX1 primers, which flanked the multiple cloning region in this plasmid. The resulting plasmid was named pPIC9BmCG (Figure 1).

\section{Cloning into Pichia pastoris}

The $P$. pastoris transformation involved electroporation in a MicroPulser apparatus (Bio-rad, USA), in accordance with the manufacturer's instructions, in the Pichia expression kit (INVITROGEN, 2009). Briefly, an $80 \mu \mathrm{L}$ aliquot of electrocompetent $P$. pastoris GS115 strain was transformed using $10 \mu \mathrm{g}$ of pPIC9BmCG linearized with SacI (Invitrogen, Australia), by applying $2.0 \mathrm{kV}$ pulses at $5 \mathrm{~ms}$ intervals. The recombinant 

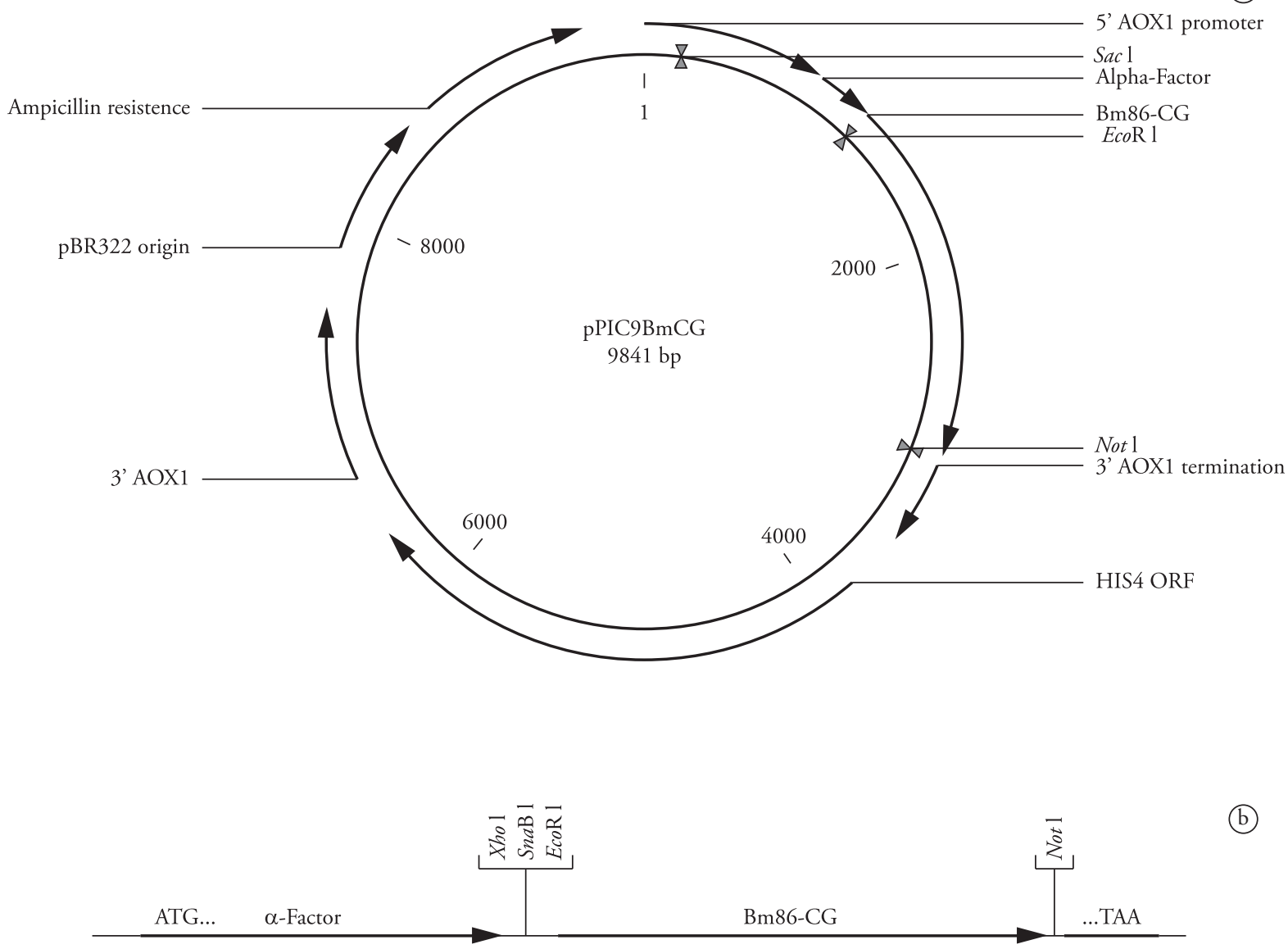

(b)

Figure 1. a) pPIC9BmCG represented using the CLC Viewer 6.0.2 software; 5'AOX1 promoter: promoter strongly induced by methanol; Sac I: enzyme used to linearize the plasmid before transformation in P. pastoris; 5'AOX1 primer: annealing site of primer 5'AOX1; Alphafactor: sequence corresponding to secreted peptide of $\mathrm{rBm} 86-\mathrm{CG}$; EcoR I: recognition sequencing of the enzyme used for cloning of 5' region; Bm86-CG: gene sequencing of Bm86-CG inserted in the plasmid; Not I: recognition sequence of the enzyme used for cloning the 3' region; 3'AOX1 termination: sequence that determines the end of the transcript; HIS4 ORF: autotrophic selection factor; pBR322 origin: replication origin for E. coli; Ampicillin resistance: selection factor that confers resistance to ampicillin for E. coli. b) Schematic representation of mRNA transcribed by pPIC9BmCG. ATG: codon start; $\alpha$-factor: corresponding sequence of peptide signal secretion of rBm86-CG; Xho I, SnaB I and EcoR I: multiple cloning site; Bm86-CG: gene sequence of Bm86-CG inserted in the plasmid; Not I: recognition sequence of the enzyme used for cloning of $3^{\prime}$ region; TAA: stop codon.

cells were selected on plates containing histidine-free MD agar (1.34\% YNB; $4 \times 10^{-5} \%$ biotin; $2 \%$ dextrose; $0.15 \%$ agar) and were incubated for 7 days at $30^{\circ} \mathrm{C}$. The clones were seeded in $10 \mathrm{~mL}$ of YPD (1\% yeast extract; $2 \%$ peptone; $2 \%$ dextrose) and incubated for 24 hours at $220 \mathrm{rpm}$ at $30^{\circ} \mathrm{C}$. A $2 \mathrm{~mL}$ volume was centrifuged at $1,500 \mathrm{xg}$ for 5 minutes, the supernatant was discarded and the cells were resuspended in $1 \mathrm{~mL}$ of YPDG (1\% yeast extract; $2 \%$ peptone; $2 \%$ dextrose; $15 \%$ glycerol) and frozen at $-80{ }^{\circ} \mathrm{C}$. The remaining $8 \mathrm{~mL}$ were used for genomic DNA extraction.

\section{Extraction of genomic DNA from clones}

Genomic DNA was extracted using the glass bead method. A $1 \mathrm{~mL}$ pellet of the culture was resuspended in $150 \mu \mathrm{L}$ of STES (2.42\% Tris base; $2.92 \%$ sodium chloride; $0.1 \%$ SDS; $0.372 \%$ EDTA; $\mathrm{pH} 7.6)$, and $50 \mu \mathrm{L}$ of glass beads $(425-600 \mu \mathrm{m}$; Sigma-
Aldrich, USA) and $150 \mu \mathrm{L}$ of phenol: chloroform: isoamyl alcohol $(12: 12: 1 \mathrm{v} / \mathrm{v})$ were added to the resuspension, in a $1.5 \mathrm{~mL}$ microtube. The system was vortexed for 1 minute and centrifuged at $13,000 \mathrm{x} g$ for 5 minutes. The supernatant was collected and precipitated with $3 \mathrm{M}$ potassium acetate at $-20^{\circ} \mathrm{C}$ for 1 hour. The tube was centrifuged at $13,000 \mathrm{xg}$ for 20 minutes. The pellet was washed with $100 \mu \mathrm{L}$ of $70 \%$ ethanol and left to dry at room temperature, after which it was eluted in $45 \mu \mathrm{L}$ of sterile Milli-Q water and left overnight at $4{ }^{\circ} \mathrm{C}$. DNA was quantified using a NanoDrop 2000c spectrophotometer (Thermo Scientific, USA) and stored at $-20^{\circ} \mathrm{C}$.

\section{Production of polyclonal sera}

Polyclonal sera against Gavac ${ }^{\mathrm{TM}}$ and TickGard ${ }^{\mathrm{PLUS}}$ vaccines, R. (B.) microplus larval extract and Bm86-CG recombinant protein (rBm86-CG) were produced using BALB/c mice. To obtain the 
larval extract, $8 \mathrm{~g}$ of larvae were frozen at $-20^{\circ} \mathrm{C}$ and macerated using a mortar and pestle. To this, $150 \mathrm{mM}$ Tris- $\mathrm{HCl}$ at $\mathrm{pH} 7.4$ was then added to make up a final volume of $8 \mathrm{~mL}$. The eluted extract was sonicated with two 10 seconds pulses at $60 \%$ amplitude and another four 10 seconds pulses at $20 \%$. The final content was syringe-filtered $(0.22 \mu \mathrm{m})$ and stored at $-20{ }^{\circ} \mathrm{C}$. The larval extract was quantified and $3 \mathrm{mg}$ of total protein were diluted in $15 \mathrm{~mL}$ of $150 \mathrm{mM}$ Tris- $\mathrm{HCl}$ at $\mathrm{pH} 7.4$ and emulsified in $15 \mathrm{~mL}$ of Freund's complete adjuvant (Sigma-Aldrich, USA). This yielded $30 \mathrm{~mL}$ of larval extract emulsion to be used as vaccine. The anti-rBm86-CG vaccine was prepared with $500 \mu \mathrm{g}$ of $\mathrm{rBm} 86-\mathrm{CG}$ protein resuspended in $5 \mathrm{~mL}$ of $150-\mathrm{mM}$ Tris- $\mathrm{HCl}$ at $\mathrm{pH} 7.4$ and emulsified with $5 \mathrm{~mL}$ of complete Freund's adjuvant (Sigma-Aldrich, USA). Twenty-four female BALB/c mice were used, which were separated into four groups of six animals. Each group received one of four vaccines at a concentration of $50 \mu \mathrm{g} \cdot \mathrm{mL}^{-1} \cdot \mathrm{dose}^{-1}\left(\mathrm{Gavac}^{\mathrm{TM}}{ }^{\text {, TickGard }}{ }^{\text {PLUS }}\right.$ or $\mathrm{rBm} 86-\mathrm{CG})$ or $100 \mu \mathrm{g} \cdot \mathrm{mL}^{-1}$.dose $\mathrm{d}^{-1}$ (larval extract vaccine). Three intramuscular doses were applied at 21-day intervals. Sera were collected 21 days after the last dose.

Inoculation of mice with $\mathrm{rBm} 86-\mathrm{CG}$ resulted in production of antibodies that reacted with both the native version of the recombinant and the native versions of the antigen, thus showing antigenicity.

\section{Screening for recombinants by dot blot}

Each clone was subcultured in $5 \mathrm{~mL}$ of BMGY medium (1\% yeast extract; $2 \%$ peptone; $100 \mathrm{mM}$ potassium phosphate at $\mathrm{pH} 6.0 ; 1.34 \% \mathrm{YNB} ; 4 \times 10^{-5} \%$ biotin; $1 \%$ glycerol) and incubated in an orbital shaker at $220 \mathrm{rpm}$ at $30{ }^{\circ} \mathrm{C}$, as were the GS115/albumin strain and one non-recombinant GS115 strain. After 24 hours of incubation, the cultures were centrifuged at $1,500 \mathrm{x} g$ for 5 minutes, the supernatant was discarded, the cells were resuspended in $5 \mathrm{~mL}$ of BMMY (1\% yeast extract; $2 \%$ peptone; $100 \mathrm{mM}$ potassium phosphate at $\mathrm{pH} 6.0 ; 1.34 \% \mathrm{YNB}$; $4 \times 10^{-5} \%$ biotin; $0.5 \%$ methanol), and the cultures were returned to the shaker for another four days. To each culture, $0.5 \%$ absolute methanol was added every 24 hours. Finally, the cultures were centrifuged and the supernatants were treated with $1 \mathrm{mM}$ PMSF and collected into $2 \mathrm{~mL}$ microtubes and frozen at $-20{ }^{\circ} \mathrm{C}$.

The PVDF membrane was washed for 10 seconds in methanol and for 5 minutes in sterile Milli-Q water. A $5 \mu \mathrm{L}$ aliquot of the supernatant from each culture and, as positive controls, $5 \mu \mathrm{L}$ each of Gavac ${ }^{\text {TM }}$ and Tick Gard ${ }^{\text {PLUS }}$, were pipetted onto a PVDF membrane and dried in an oven at $30{ }^{\circ} \mathrm{C}$. The membrane was blocked with phosphate-buffered saline (PBS) containing 5\% nonfat dried milk under stirring for 1 hour at $30{ }^{\circ} \mathrm{C}$ and subsequently washed twice ( 5 minutes each time) with PBS-T (PBS containing $0.1 \%$ Tween $80 ; \mathrm{pH} 7.4)$. Next, the membrane was incubated under stirring for 1 hour at $30^{\circ} \mathrm{C}$ with mouse-produced primary polyclonal antibodies, from animals vaccinated with Gavac ${ }^{\mathrm{TM}}$ or TickGard ${ }^{\text {PLUS }}$, diluted 1:150 in PBS. This was followed by three washes with PBS-T, and by incubation under stirring for 1 hour at $30{ }^{\circ} \mathrm{C}$ with peroxidase-conjugated rabbit anti-mouse IgG secondary antibody (Sigma-Aldrich, USA), diluted 1:1000 in PBS-T. Finally, the material was washed another three times $(5$ minutes each) with PBS-T and incubated in $5 \mathrm{~mL}$ of developing solution (0.5\% diaminobenzidine; $0.075 \%$ urea) until the appearance of coloration on the membrane, which was washed in sterile Milli-Q water and photodocumented.

\section{Screening for $\mathrm{Mut}^{+}$and $M u t^{5}$}

Recombinant cells can be generated into two phenotypic classes: Mut ${ }^{+}$and $\mathrm{Mut}^{\mathrm{S}}$. The $\mathrm{Mut}^{\mathrm{S}}$ (methanol utilization slow) phenotype results from loss of activity of the alcohol oxidase caused by a mutation in the AOX1 (alcohol oxidase 1) gene.

\section{Sequencing}

The PCR products from genomic DNA of clone B (Mut $\left.{ }^{+}\right)$ were sequenced with primers designed for the $\mathrm{pAOX} 1$ promoter, in an ABI 3100 automated sequencer using BigDye Terminator chemistry, in accordance with the manufacturer's instructions. The sequencing results were compared with the Bm86-CG using ClustalW software for sequence alignment.

\section{Production of Bm86-CG}

To determine the rBm86-CG expression, one colony from clone $\mathrm{B}\left(\mathrm{Mut}^{+}\right)$was isolated on plates containing solid MD medium. Colonies of the strains GS115/albumin and non-recombinant GS115 (Invitrogen, Australia) were also isolated as positive and negative controls respectively. The colonies were inoculated in a $250 \mathrm{~mL}$ Erlenmeyer flask containing $25 \mathrm{~mL}$ of BMGY medium, and incubated overnight in an orbital shaker at $220 \mathrm{rpm}$ at $30^{\circ} \mathrm{C}$ until reaching $\mathrm{OD}_{600 \mathrm{~nm}}=4$, after approximately 16-18 hours. The cultures were subsequently centrifuged at $1,500 \mathrm{x} g$ for 5 minutes at room temperature and the supernatants were discarded. The precipitates of clone B and GS115 were resuspended in $2 \mathrm{~L}$ of Erlenmeyer's solution with BMMY medium until reaching $\mathrm{OD}_{600 \mathrm{~nm}}=1.0$, at an approximate volume of $200 \mathrm{~mL}$. To each culture, $1 \%$ absolute methanol was added every 24 hours, for an induction period of 96 hours. The induction was maintained by addition of $1 \%$ methanol every 24 hours, for a period of 96 hours. After induction, the cultures were centrifuged at $3,300 \mathrm{x}$ g at $4{ }^{\circ} \mathrm{C}$ for 5 minutes and the supernatants were separated, treated with $1 \mathrm{mM}$ PMSF and frozen at $-20{ }^{\circ} \mathrm{C}$ until quantification time.

\section{Quantification of $r B m 86-C G$}

The supernatants from the material expressed by clones B and $\mathrm{D}$ were quantified by means of the standard curve method with bovine serum albumin (BSA) on $7.5 \%$ SDS-PAGE. BSA was previously prepared as a $1 \mu \mathrm{g} . \mu \mathrm{L}^{-1}$ solution. $25 \mu \mathrm{L}$ of this solution were added to $10 \mu \mathrm{L}$ of SDS-PAGE sample buffer and $15 \mu \mathrm{L}$ of sterile Milli-Q water, yielding $50 \mu \mathrm{L}$ of $0.5 \mu \mathrm{g} \cdot \mu \mathrm{L}^{-1}$ BSA solution. Aliquots of $1,2,4,6$, and $8 \mu \mathrm{L}$ of this solution were applied on $7.5 \%$ polyacrylamide gel, in quantities of $0.5,1,2,3$, and $4 \mu \mathrm{g} . \mu \mathrm{L}^{-1}$, respectively, along with the samples to be quantified. The bands formed on the gel were quantified by visual analysis and also 
using the TotalLab 2.0 software (Amersham Biosciences, United Kingdom), which also served to estimate the apparent molecular mass of bands.

\section{SDS-PAGE and Western blot for rBm86CG}

$50 \mu \mathrm{L}$ of both supernatants of clone B, clone D, GS115 and GS115/albumin were mixed with $10 \mu \mathrm{L}$ of denaturing buffer 6x SDS-PAGE, separately. The samples were incubated for 6 minutes at $95^{\circ} \mathrm{C}$, left to cool down and pipetted $(20 \mu \mathrm{L})$ on $7.5 \%$ polyacrylamide gel. Electrophoresis was run for 1.5 hour at $30 \mathrm{~mA}$ in a 2D electrophoresis system (Amersham Biosciences, United Kingdom). Western blot analysis was performed on material from a $7.5 \%$ polyacrylamide gel run with $10 \mu \mathrm{L}$ of clone B supernatant. The protein was transferred from the gel to a Polyvinylidene fluoride (PVDF) membrane (pretreated with methanol for 10 seconds and sterile Milli-Q water for 5 minutes) using a transfer system (Amersham Biosciences, United Kingdom) immersed in transfer buffer $(0.3 \%$ Tris base; $1.44 \%$ glycine; $15 \%$ methanol; $\mathrm{pH} 8.4$ ) at $100 \mathrm{~mA}$ for 2 hours. The membrane was washed with PBS, left to dry in an stove at $25{ }^{\circ} \mathrm{C}$ for 1 hour, stained with Ponceau $S$ solution ( $0.5 \%$ Ponceau S; $1 \%$ glacial acetic acid), and cut into strips. The strips were blocked with PBS containing $5 \%$ nonfat dried milk at $30^{\circ} \mathrm{C}$ for 1 hour under stirring, washed twice with PBS-T for 5 minutes and incubated with primary antibody at $1: 150$ in $\mathrm{PBS}$ at $30^{\circ} \mathrm{C}$ for 1 hour under stirring (one strip for each type of serum: anti-Gavac, anti-TickGard, anti-larval extract and anti-rBm86-CG). They were subsequently washed twice for 5 minutes with PBS-T and separately incubated with peroxidase-conjugated rabbit anti-mouse IgG secondary antibody (Sigma-Aldrich, USA), 1:1000 in PBS-T at $30^{\circ} \mathrm{C}$ for 1 hour under stirring. The strips were washed another three times for 5 minutes with PBS-T, rinsed in sterile Milli-Q water and developed ( $5 \mathrm{~mL}$ of Milli-Q water; $5 \mathrm{mg}$ of DAB; $0.75 \mathrm{mg}$ of $\mathrm{NH}_{4}$ ) until well-defined bands (5-10 seconds) appeared on the PVDF membrane.

As a negative control, the supernatant from non-recombinant P. pastoris GS115 was used as the antigen in Western blotting with serum of mice immunized against Gavac vaccine.

\section{Antigen preparation and animal vaccinations}

The vaccine was prepared with $\mathrm{rBm} 86-\mathrm{CG}$ expressed in yeast, as reported above, by mixing the emulsified antigen with equal volumes of Montanide (ISA 61 VG; Seppic, Paris, France) using an ultra-homogenizer. Each vaccine consisted of $1 \mathrm{~mL}$ containing $100 \mu \mathrm{g}$ of rBm86-CG combined with $1 \mathrm{~mL}$ of adjuvant.

A total of 12 month old dairy steers ( $82 \%$ cross-bred Friesian), without previous exposure to $R$. (B.) microplus, were used in this study. Each animal was randomly allocated to an immunized or a control group of six cattle each. The vaccinated animals were immunized with $\mathrm{rBm} 86-\mathrm{CG}$ and the negative control group was injected with phosphate-buffered saline (PBS). The animals were housed in pens and were fed concentrates daily, and provided with hay and water throughout the study. Blood samples were collected weekly. The cattle were inoculated intramuscularly three times at two-week intervals.

\section{Enzyme-linked immunosorbent serological assay (ELISA)}

Sera from each group were collected weekly and antibody levels were determined by means of ELISA with rBm86-CG. Microtiter plates were coated with $100 \mathrm{ng}$ of $\mathrm{rBm} 86-\mathrm{CG}$ per well in $100 \mathrm{mM}$ carbonate buffer ( $\mathrm{pH} 9.8$ ), washed three times at each step with PBS containing $0.05 \%(\mathrm{v} / \mathrm{v})$ Tween-20, blocked with $0.5 \%$ skimmed milk powder diluted in PBS, and the antisera used as the primary antibody was diluted 1:500. Horseradish peroxidase-conjugated rabbit anti-bovine IgG (SIGMA, Steinheim, Germany) was diluted 1:5000 to serve as a secondary antibody, and antigen-antibody complexes were detected with $4.10^{-4} \%$ o-phenylenediamine (OPD; SIGMA, Steinheim, Germany) and $0.1 \% \mathrm{H}_{2} \mathrm{O}_{2}$, before optical densities at $490 \mathrm{~nm}$ were measured. Additional controls without antigen, primary antibody, secondary antibody or substrate were read to ensure that the colorimetric reaction was because of the formation of antigen-antibody complexes and not because of non-specific reactions.

Anti-rBm86-CG IgG titers were determined by means of ELISA as described above. Titers from individual animals were expressed as the maximum dilution having an $\mathrm{OD}_{492 \mathrm{~nm}}$ higher than two times the average from a seronegative bovine.

To analyze the antibody response results from vaccination experiments in the pen trial, mean antibody levels were compared using an ANOVA test $(\mathrm{p}<0.01)$. All analyses were carried out using the SAS software v. 9.1.

\section{Results}

\section{Construction of pPIC9BmCG}

Recombinant plasmid was built by inserting the Bm86-CG protein gene sequence into the multiple cloning site of the pPIC9 plasmid, between the $E c o \mathrm{R} I$ and Not I restriction enzymes (Figure 1). The sequence of the insert was confirmed by sequencing and alignment with Bm86-CG (GenBank accession no. EU352677.1), with $100 \%$ identity. The sequence was cloned taking into account the expression cassette controlled by the AOX1 gene promoter. The multiple cloning was maintained so as to precede the Bm86-CG sequence, thus allowing other sequences and subsequent cloning (e.g. a sequence modulating the immune response). The absence of a purification system in this plasmid precluded performing affinity chromatography to purify the protein.

\section{AOX1 gene mutation analysis}

The plasmid cloned into $P$. pastoris was previously linearized with the SacI enzyme to allow for two types of integration into the yeast genome, thus resulting in two possible phenotypes: Mut ${ }^{s}$, with AOX1 gene mutation; and $\mathrm{Mut}^{+}$, with the conserved gene. Clonal variation requires testing of recombinants for both phenotypes, since their capabilities to express the recombinant protein cannot be compared beforehand. In the present study, 
the clone for phenotype $\mathrm{Mut}^{+}$expressed recombinant protein in greater amounts than did the clone for Muts.

\section{3. $r B m 86-C G$ protein expression}

Clone B $\left(\mathrm{Mut}^{+}\right)$was selected and induced to expression. Analysis of the supernatants on 7.5\% SDS-PAGE for protein expression revealed bands of approximately $80 \mathrm{kDa}$ (Figure 2). The expected molecular weight of $69.1 \mathrm{kDa}$ for the rBm86-CG protein expressed in this system was calculated using CLC Viewer 6.0.2 software. The difference can be explained by the fact that rBm86-CG has a glycosylation site in its amino acid sequence, with a resultant larger molecular weight on SDS-PAGE.

\section{Expression quantification}

Direct quantification from culture supernatants revealed rBm86-CG production levels of 62.5 and $32 \mathrm{mg} . \mathrm{L}^{-1}$ with regard to $\mathrm{Mut}^{+}$and Mut $\mathrm{M}^{\mathrm{s}}$, respectively.

\section{Western blotting}

Western blot analysis on the rBm86-CG protein was carried out using four primary sera from mice: anti-Gavac ${ }^{\mathrm{TM}}$, anti-TickGard ${ }^{\mathrm{PLUS}}$, anti-R. (B.) microplus larval extract and anti-rBm86-CG. It revealed affinity for a protein of approximately $80 \mathrm{kDa}$ (Figure 3). Western blot using the larval extract as an antigen and anti-rBm86-CG as a bovine antibody revealed that immunized bovine with r-BmCG recognized native antigen with the expected protein size (Figure 3).

\section{Enzyme-linked immunosorbent serological assay}

Before the first immunization, serum samples were assayed by means of ELISA for anti-rBm86-CG antibodies and were

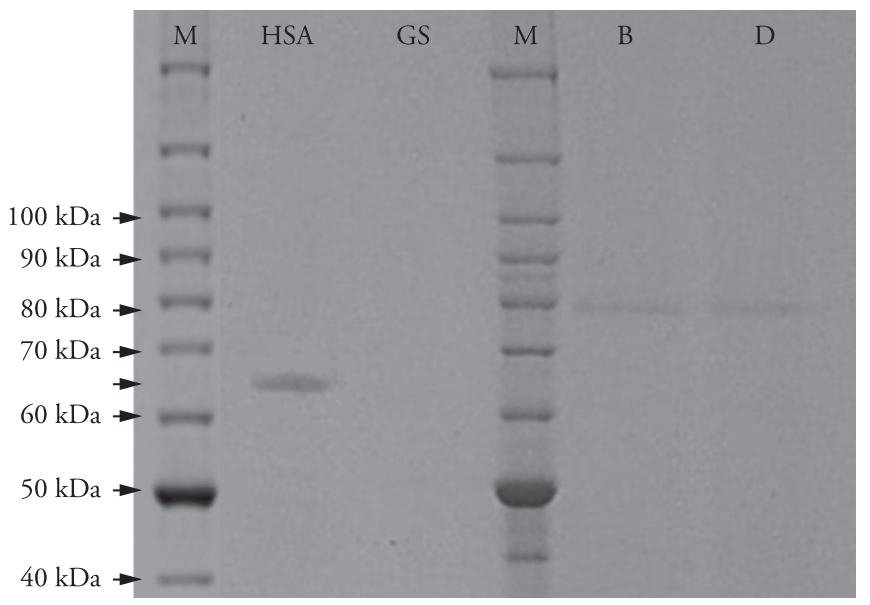

Figure 2. Analysis on recombinant proteins using SDS-PAGE: 7.5\% of supernatants from clone B $\left(\mathrm{Mut}^{+}\right)$and clone D $\left(\mathrm{Mut}^{\mathrm{s}}\right)$. HSA: supernatant GS115/albumin; GS: supernatant GS115; M: BenchMark ${ }^{\text {тM }}$ Protein Ladder standard for SDS-polyacrylamide gel electrophoresis ranging in molecular weight from 10 to $220 \mathrm{kDa}$. B: supernatant of the expression of clone $\mathrm{B}$; D: supernatant of the expression of clone $\mathrm{D}$. found to be seronegative. Specific antibody levels in sera from immunized animals increased one week after the first immunization, while sera from controls remained negative (Figure 4). Antibody levels increased one week after the second inoculation, in all the immunized animals. A better response was observed in week 8 , which occurred after a small decline. The trends of specific antibody levels increased after every inoculation. However, sera from $\mathrm{rBm} 86$-CG-immunized cattle demonstrated the highest level of antibodies for $\mathrm{rBm} 86-\mathrm{CG}$ throughout the study, and no significant titers to rBm86-CG were observed among the control group sera.

Following the immunization using the rBm86-CG-based vaccine (in weeks 0,2 and 4), all the experimental animals developed a strong and specific humoral immune response characterized by high anti-rBm86-CG IgG titers. Specific antibody titers were in all cases over 1:640. However, in the eighth week, specific antibody titers were over 1:2560.

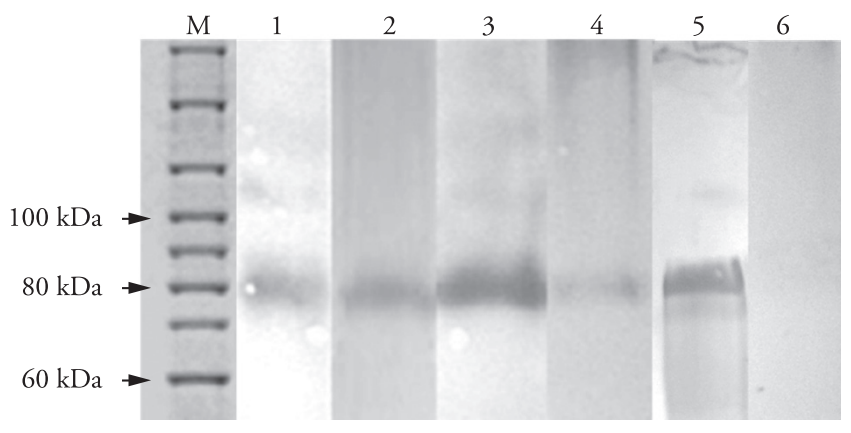

Figure 3. Western blot gel of rBm86-CG expressed by clone B. 1: anti-Gavac serum; 2: anti-TickGard serum; 3: anti-larval extract serum; 4: anti-rBm86-CG serum; 5: larval extract as antigen recognized with bovine serum immunized with rBm86-CG; 6: Negative control. M: BenchMark ${ }^{\text {тM }}$ Protein Ladder standard for SDS-polyacrylamide gel electrophoresis ranging in molecular weight from 10 to $220 \mathrm{kDa}$.

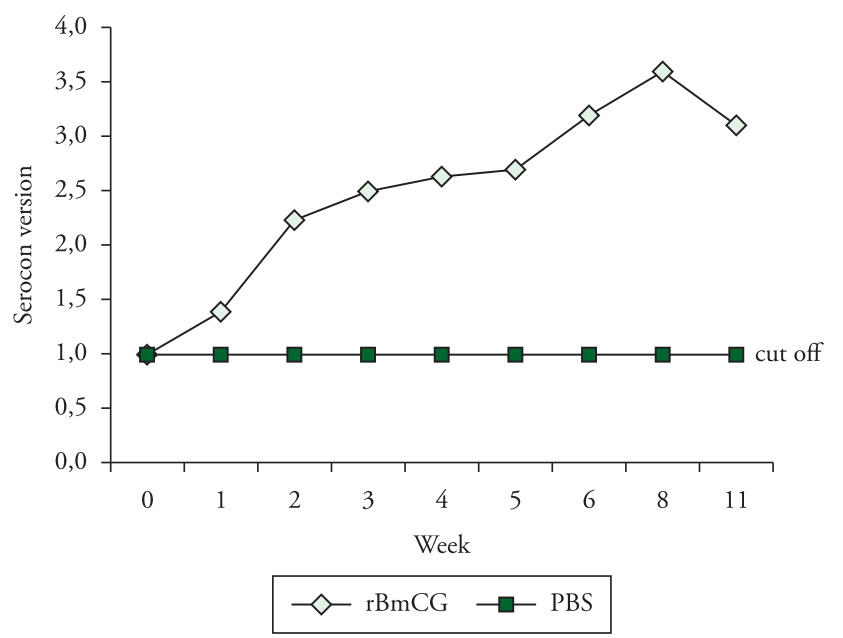

Figure 4. Recognition of rBm86-CG by antisera from cattle immunized with antigens. Seroconversion from ELISA tests of weekly antisera samples collected from two groups of six cattle immunized at 0,2 and 4 weeks with $\mathrm{rBm} 86-\mathrm{CG}$ (dark line) and phosphatebuffered saline (light line). 


\section{Discussion}

The system of expression in $P$. pastoris selected for this investigation is currently efficient for producing heterologous proteins, requires fewer procedures, offers lowering production costs and is also superior to prokaryotic systems in relation to its capacity to express proteins in their correct three-dimensional structure.

A pPIC9BmCG plasmid was successfully constructed and proved capable of effectively expressing the recombinant rBm86-CG protein. Since latter is soluble in the culture medium, it can easily be obtained by precipitation from the supernatant, which will facilitate the purification process and thus lead to a reduction in the production cost.

In addition to being simpler than purification from cell membranes or cytoplasm, the method preserves the antigenic and immunogenic properties of the expressed protein, which is important for producing an effective immunogen.

SDS-PAGE showed a well-defined majority band of approximately $80 \mathrm{kDa}$, corresponding to $\mathrm{rBm} 86-\mathrm{CG}$, which should weigh $69.1 \mathrm{kDa}$ (as calculated using the CLC Viewer 6.0.2 software). However, this value does not take into account eukaryotic protein modification such as glycosylation, disulfide bond formations and proteolytic processing.

Recognition of $\mathrm{rBm} 86-\mathrm{CG}$ by the anti-Gavac ${ }^{\mathrm{TM}}$ serum revealed that the system was capable of expressing a recombinant protein that had similar antigenic properties and was recognizable by antibodies generated by this vaccine. Considering that the $\mathrm{Bm} 86$ antigen contained in $\mathrm{Gavac}^{\mathrm{TM}}$ was also expressed in $P$. pastoris, sera produced by the TickGard ${ }^{\text {PLUS }}$ vaccine served as controls. Since their antigen was produced in E. coli, they failed to produce antibodies against $P$. pastoris, thus confirming that the protein revealed on Western blotting is not a product of the yeast. Western blot analysis demonstrated that Bm86-CG expressed in P. pastoris was recognized by antibodies, since it was recognized by antibodies generated by both the TickGard and the Gavac vaccine. One particularly important finding is that $\mathrm{rBm} 86-\mathrm{CG}$ was recognized by the antibodies against the larval extract vaccine, which contains native Bm86-CG. This finding confirms that a recombinant protein immunogenically similar to native Bm86-CG was expressed, thus suggesting that the recombinant form is a potential antigen for use in cattle vaccines. Recognition of $\mathrm{rBm} 86-\mathrm{CG}$ by anti-rBm86-CG sera shows that the protein was capable of inducing an immune response. Analysis of the membrane revealed that there were no responses to other possible proteins, since the vaccine was prepared with the complete expressed supernatant.

The expression system selected for this investigation allowed $\mathrm{rBm} 86-\mathrm{CG}$ to be produced in vitro at a concentration of $62.5 \mathrm{mg} . \mathrm{L}^{-1}$, which is an improvement in comparison with another study, in which the expression levels ranged between 1.0 and $6.0 \mathrm{mg} . \mathrm{L}^{-1}$, thus representing 1.5 to $13.2 \%$ of the total proteins in the supernatant. Nevertheless, in this study, when rBm86-CG was subjected to fermentation, the expression level rose initially to $150 \mathrm{mg} . \mathrm{L}^{-1}$, thus representing at least a 50 -fold increase (CANALES et al., 2008). The highest published protein production in $P$. pastoris was 1.5 g.L $\mathrm{L}^{-1}$, in a fermenter (RODRÍGUEZ et al., 1994)
The goal of using a eukaryotic expression system to produce a regional antigen with a potential for use in vaccines was thus achieved in the present investigation.

The anti-rBm86-CG antibody levels in cattle immunized with rBm86-CG were significantly higher than the levels in the cattle. No specific antibodies against the rBm86-CG immunogen were detected in pre-immunization serum $(\mathrm{p}<0.01)$. These results indicated that rBm86-CG-based vaccine was immunogenic and induced production of antibodies that recognized $\mathrm{rBm} 86-\mathrm{CG}$.

It has now been demonstrated that certain amounts of antibodies against $\mathrm{rBm} 86$ correlate with damage to ticks engorging on immunized cattle (DE LA FUENTE et al., 1998; VARGAS et al., 2010). Previous experiments have also suggested that a damaging effect mediated by specific antibodies can be expected in these ticks engorging on immunized cattle, with a titer cutoff of 1:640 (DE LA FUENTE et al., 1998).

The antibody responses in vaccinated animals indicated that this phase of the study was successful, and that vaccines formulated with rBm86-CG are capable of eliciting high antibody titers in cattle.

\section{Acknowledgements}

We are grateful to Embrapa Beef Cattle and CNPq (Brazil) for their financial support for this investigation; to CAPES for a postgraduate fellowship; and to Seppic for providing us with the adjuvant and its technical information.

\section{References}

ANDREOTTI, R. et al. Comparison of predicted binders in Rhipicephalus (Boophilus) microplus intestine protein variants Bm86 Campo Grande strain, Bm86 and Bm95. Revista Brasileira de Parasitologia Veterinária, v. 17, n. 2, p. 93-98, 2008.

ANDREOTTI, R. Performance of two Bm86 antigen vaccin formulation against tick using crossbreed bovines in stall test. Revista Brasileira de Parasitologia Veterinária, v. 15, n. 3, p. 97-100, 2006.

CANALES, M. et al. Expression of recombinant Rhipicephalus (Boophilus) microplus, $R$. annulatus and $R$. decoloratus $\mathrm{Bm} 86$ orthologs as secreted proteins in Pichia pastoris. BMC Biotechnology, v. 8, p. 14, 2008. PMid:18275601. PMCid:2262073. http://dx.doi.org/10.1186/14726750-8-14

CANALES, M. et al. Vaccination with recombinant Boophilus annulatus $\mathrm{Bm} 86$ ortholog protein, $\mathrm{Ba} 86$, protects cattle against $B$. annulatus and B. microplus infestations. BMC Biotechnology, v. 9, p. 29, 2009. PMid:19335900. PMCid:2667501. http://dx.doi.org/10.1186/14726750-9-29

DE LA FUENTE, J. et al. Field studies and cost-effectiveness analysis of vaccination with Gavac ${ }^{\mathrm{TM}}$ against the cattle tick Boophilus microplus. Vaccine, v. 16, n. 4, p. 366-373, 1998. http://dx.doi.org/10.1016/ S0264-410X(97)00208-9

DE LA FUENTE, J. et al. Vaccination against ticks (Boophilus spp.): the experience with the Bm86-based vaccine Gavac. Genetic Analysis, v. 15, n. 3-5, p. 143-148, 1999.

DE LA FUENTE, J.; KOCAN, K. M. Advances in the identification and characterization of protective antigens for recombinant vaccines against 
tick infestations. Expert Review of Vaccines, v. 2, n. 4, p. 583-593, 2003. PMid:14711342. http://dx.doi.org/10.1586/14760584.2.4.583

FURLONG, J. Controle estratégico do carrapato dos bovinos. A Hora Veterinária, v. 23, p. 53-56, 2004.

GARCÍA-GARCÍA, J. C. et al. Control of ticks resistant to immunization with $\mathrm{Bm} 86$ in cattle vaccinated with the recombinant antigen Bm95 isolated from the cattle tick, Boophilus microplus. Vaccine, v. 18, n. 21 , p. $2275-2287,2000$. http://dx.doi.org/10.1016/S0264410X(99)00548-4

GARCÍA-GARCÍA, J. C. et al. Sequence variations in the Boophilus microplus $\mathrm{Bm} 86$ locus and implications for immunoprotection in cattle vaccinated with this antigen. Experimental and Applied Acarology, v. 23, n. 11, p. 883-895, 1999. http://dx.doi.org/10.1023/A:1006270615158

GOUGH, J. M.; KEMP, D. H. Localization of a low abundance membrane protein $(\mathrm{Bm} 86)$ on the gut cells of the cattle tick Boophilus microplus by immunogold labeling. Journal of Parasitology, v. 79, n. 6, p. 900-907, 1993. http://dx.doi.org/10.1016/S0165-2427(02)00154-X

INVITROGEN. Pichia expression kit. for expression of recombinant proteins in Pichia pastoris. 2009. Catalog no. K1710-01.

PATARROYO, J. H. et al. Immunization of cattle with synthetic peptides derived from the Boophilus microplus gut protein (Bm86). Veterinary Immunology and Immunopathology, v. 88, n. 3-4, p. 163-172, 2002. http://dx.doi.org/10.1016/S0165-2427(02)00154-X

RAND, K. N. et al. Cloning and expression of a protective antigen from the cattle tick Boophilus microplus. Proceedings of the National Academy of Sciences, v. 86, n. 24, p. 9657-9661, 1989. http://dx.doi. org/10.1073/pnas.86.24.9657

RICHARDSON, M. A. et al. Native and baculovirus-expressed forms of the immuno-protective protein BM86 from Boophilus microplus are anchored to the cell membrane by a glycosyl-phosphatidyl inositol linkage. Insect Molecular Biology, v. 1, n. 3, p. 139-147, 1993. PMid:8269092. http://dx.doi.org/10.1111/j.1365-2583.1993.tb00115.x

RIDING, G. A. et al. A protective "concealed" antigen from Boophilus microplus. Purification, localization, and possible function. Journal of Immunology, v. 153, n. 11, p. 5158-5166, 1994.
RODRÍGUEZ, M. et al. Effect of vaccination with a recombinant Bm86 antigen preparation on natural infestations of Boophilus microplus in grazing dairy and beef pure and cross-bred cattle in Brazil. Vaccine, v. 13, n. 18, p. 1804-1808, 1995. http://dx.doi.org/10.1016/0264410X(95)00119-L

RODRÍGUEZ, M. et al. High level expression of the B. microplus Bm86 antigen in the yeast Pichia pastoris forming highly immunogenic particles for cattle. Journal of Biotechnology, v. 33, n. 2, p. 135-146, 1994. http://dx.doi.org/10.1016/0168-1656(94)90106-6

VARGAS, M. et al. Two initial vaccinations with the Bm86-based Gavac ${ }^{\text {plus }}$ vaccine against Rhipicephalus (Boophilus) microplus induce similar reproductive suppression to three initial vaccinations under production conditions. BioMed Central Veterinary Research, p. 6-43, 2010 .

WILEY, J. Current protocols in molecular biology. 2003. p. 4410.

WILLADSEN, P. et al. Immunologic control of a parasitic arthropod. Identification of a protective antigen from Boophilus microplus. Journal of Immunology, v. 143, n. 4, p. 1346-1351, 1989. PMid:2745982.

WILLADSEN, P. Novel vaccines for ectoparasites. Veterinary Parasitology, v. 71, n. 2-3, p. 209-222, 1997. http://dx.doi.org/10.1016/ S0304-4017(97)00028-9

WILLADSEN, P., KEMP, D. H. Vaccination with 'concealed' antigens for tick control. Parasitology Today, v. 4, n. 7, p. 196-198, 1988. http:// dx.doi.org/10.1016/0169-4758(88)90084-1

WILLADSEN, P.; JONGEJAN, F. Immunology of the tick-host interaction and the control of ticks and tick-borne diseases. Parasitology Today, v. 15, n. 7, p. 258-262, 1999. http://dx.doi.org/10.1016/S01694758(99)01472-6

WILLADSEN, P.; McKENNA, R. V. Vaccination with 'concealed' antigens: myth or reality? Parasite Immunology, v. 13, n. 6, p. 605-616, 1991. PMid:1725819. http://dx.doi.org/10.1111/j.1365-3024.1991. tb00556.x 